Robert PAKLA*

\title{
Health tourism and Cross-border healthcare IN THE EUROPEAN UNION
}

\section{Introduction}

A free movement of persons and freedom to provide services in the European Union (EU) had a great influence on many areas of people's lives in Europe. One of the areas is an access to healthcare services. Differential standard of services and legitimacy of treatments that are being performed in individual European countries contributed in emergence of a new phenomenon which is health tourism. It has to be mentioned that the phenomenon that is being discussed is not only a social problem. Patient's rights to obtain a healthcare in other Member States and reimbursement of treatment as a part of national social security systems is now the subject of an active debate in the European forum. On the one hand, an issue of a freedom to flow of health services in the internal market is essential and on the other hand the autonomy of membership countries to shape their national social security systems is meaningful too ${ }^{1}$. As long as medical procedures are being made in order to save lives in other Member States, there are no doubts in regard to law and morality. Therefore, emi-

* Doctoral student at The John Paul II Catholic University of Lublin; e-mail: rpakla@ gmail.com.

${ }^{1}$ S. Biernat (eds.), S. Dudzik (eds.), D. Adamski, D. Bach-Golecka, A. Czekaj-Dancewicz, P. Dąbrowska, M. Glicz, I. Grzywacz, O. Hołub-Śniadach, K. Karasiewicz, M. Kawczyńska, I. Kawka, D, Leczykiewicz, D. Lutostańska, K. Majcher, S. Majkowska-Szulc, L. Mitrus, J. Nawrot, M. Niedźwiedź, A. Sikora, K. Strąk, M. Tomaszewska, K. Tosza, J. Wsołek, Przepływ osób i świadczenie ustug w Unii Europejskiej, LEX 2009, http://lex.online. wolterskluwer.pl. 
gration to European countries in order to have a treatment which is illegal in the homeland of a particular person can raise doubts. The present text is aimed at characteristics of health tourism, its definition and analysis of benefits and potential threats that can possibly arise from the emergence of this phenomenon. Undoubtedly, the problems mentioned below are partially solved by the case law of the European Court of Justice, however the development of technology, particularly in health care services sector cause the necessity of upgrading the subject matter in legal point of view. In the text there are references to the European Regulations including Treaty establishing the European Community ${ }^{2}$, Regulations of the European Parliament and the Council (EC) No 883/2004 of 29 April 2004 on the coordination of social security systems ${ }^{3}$, Regulation of the European Parliament and Council (EC) No 987/2009 of 16 September 2009 lying down the procedure for implementing Regulation (EC) No 883/2004 on the coordination of social security systems ${ }^{4}$.

The text concerns also to not anymore binding Regulation coordinating No1408/715 and Council Regulation (EEC) No 574/72 of 21 March 1972 because of the major role in shaping current legislation.

Directive of the European Parliament and of the Council 2011/24/EU of 9 March $2011^{7}$ also play a major role. According to the Regulation, the insured person has a choice, between a reimbursement from the institution of the receiving State (or Member State of treatment) and that of the com-

2 Treaty on the Functioning of the European Union - OJ C 326, 26.10.2012, hereinafter referred as TFE; Treaty of Lisbon amending the Treaty on European Union and the Treaty establishing the European Community, Lisbon, 2007.12.12 - OJ C2007/306/1, hereinafter referred as TEC.

${ }^{3}$ Regulations of the European Union Parliament and the Council (EC) No 883/2004 of April 2004 on the coordination of social security systems; text with relevance for the EEA and for Switzerland - OJ L 200, 7.6.2004, hereinafter referred as a Regulation No 883/2004.

${ }^{4}$ Regulation of the European Parliament and Council (EC) No 987/2009 of 16 September 2009 lying down the procedure for implementing Regulation (EC) No 883/2004 on the coordination of social security systems; text with relevance for the EEA and for Switzerland - OJ L 284, 30.10.2009, hereinafter referred as a Regulation No 987/2009.

${ }^{5}$ Council Regulation (EEC) No 1408/71 of 14 June 1971 on the application of social security schemes to employed persons and their families moving within the Community, with a view to applying it to self-employed persons and their families; Consolidated text - OJ L 28, 30.1.1997.

${ }^{6}$ Council Regulation (EEC) No 574/72 of 21 March 1972 on implementing Regulation (EEC) No 1408/71; text consolidated - OJ L 28, 30.1.1997.

${ }^{7}$ Directive 2011/24/EU of the European Parliament and of the Council of 9 March 2011 on the application of patients' rights in cross-border healthcare-OJ L 88, 4.4.2011. 
petent State (or Member State of affiliation). Thus, the complementarily of the two normative systems is fully recognized. Within this framework, it is likely that patients will continue to favor cross - border reimbursement for healthcare based on the Regulation, inasmuch as it exempts them from paying fees up front - fees that are borne by the institution of the State providing the care and then reimbursed by the competent institution of the State of affiliation. This clarification of the reimbursement procedure dovetails with improved accuracy in the procedural safeguards for the patient ${ }^{8}$. What is also important Directive of the European Parliament and of the Council 2011/24/EU of 9 March 2011 tries to establish status of European patient. This effort can be beginning of uniformity of terms and conditions patients should be treated in whole European Union. What is characteristic in Directive there is distinction between non - hospital care and hospital care. This kind of solutions may in the future provide the basis for the implementation of regulations concerning the protection of consumers of private medical services.

The text does not address issues related to cross-border healthcare for people from beyond the European Union due to the content of this publication.

\section{The idea and characteristics of health tourism and cross-border healthcare}

When trying to define and characterize a term of health tourism, one must realize that this term exists in the world for many years. Beginning with a travel to the Roman thermal baths, through an exclusive holidays in Swiss resorts and finally to the incredible progress of this phenomenon in recent years. Due to the spread of travels abroad, ever-cheaper plane tickets and borders of many countries being opened for tourists, health tourism is becoming a multi-billion-business with great benefits, but also potential threats.

At the current stage of development of European social law, the statement expressed by Advocate General Lenz about the Cowan issue that

${ }^{8}$ S. De la Rosa, The Directive on cross-border healthcare or the art of codifying complex case law, “Common Market Law Review" 2012, vol. 49, p. 15-46. 
"health tourism, in other words movement of persons within the Community with the sole intention of using more attractive social care is not one of the objectives of the Community provided in the Treaty ${ }^{9 \prime \prime}$ has lost its validity. The expression of new tendencies can be even European Charter of Patients' Rights. This is an informal non-governmental document. The document was drawn up in 2002 by the organization Active Citizenship Network ${ }^{10}$ in collaboration with 12 organizations from different countries of the European Union: Apovita (Portugal), Cittadinanzattiva (Italy), Confederación de Consumidores y Usurarios (Spain), Danish Consumer Council (Denmark), Deutsche Gesellschaft für Versicherte und Patienten e. V. (Germany), Fédération Belge contre le Cancer (Belgium), International Neurotrauma Research Organization (Austria), Irish Patients Association Ltd (Ireland), KE.P.K.A (Greece), Nederlandse Patiënten Consumenten Federatie (Netherlands), The Patients Association (Great Britain), Vereniging Samenwerkende Ouderen Patiëntenorganisaties (Netherlands). The European Charter of Patients' Rights includes 14 patient's rights, which altogether lead to guarantee of "high level of protection of human health" (article. 35 of the Charter of Fundamental Rights of the European Union ${ }^{11}$ ) and to assure high quality services provided by different health systems in Europe.

These 14 laws are the embodiment of the fundamental laws and they must be considered and obeyed as such. They are connected with duties and responsibilities, which are the obligation for both citizens of the state and all participants of the healthcare system. The Charter is addressed to all people, considering the fact that differences in age, sex, religion, socio-economic status, etc., can affect on individual needs in terms of healthcare. The Charter contains 3 active citizenship rights. They allow individuals and groups of citizens to promote, monitor and control the respect for

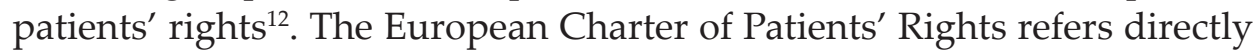
to the fact that every patient has a right to choose the place of treatment.

9 Opinion of a Advocate General Lenz of 6 December 1988 on case 186/87 Ian William Cowan v Tresor public, [1989] ECR, p. 195, paragraph 39.

${ }^{10}$ www.activecitizenship.net [access: 27.11.2016]; Active Citizenship Network is a European network focalizing about 100 civil organizations from 30 countries, promoted by an Italian organization Cittadinanzattiva. Its action is to contribute to the development of an active citizenship in the European Union.

${ }^{11}$ Consolidated version of Charter of Fundamental Rights of the European Union of 30 May 2010 - OJ C 326 from 26.10.2012.

12 http://www.prawapacjenta.eu/?pId=443 [access: 27.11 .2016$]$. 
At this point one must refer to the regulations contained in the Directive 2011/24/EU of the European Parliament and of the Council of 9 March 2011 on the application of patients' rights in cross-border healthcare. This Directive provides a creation of general framework for: explanation of patients' rights in terms of their access to cross-border healthcare and reimbursement, warranty of quality and security of care that patients receive in another EU country, promotion of cooperation between Member States in the field of healthcare. It does not address to the crucial issue which is long-term healthcare. The reason why the European legislator omitted such an important case is not understandable. In author's opinion, this issue is a key element of cross-border healthcare. The Directive explicitly stated that each Member State must indicate one or several national contact points, which will provide cross-border healthcare. The contact points consult with patient organizations, healthcare providers and providers of healthcare insurance. If patients decide to make use of cross-border healthcare, contact points have a duty to provide information about patients' rights as well as the data of other contact points in other Member States. Member State of treatment provides and organizes healthcare. It watches over the compliance with quality and safety standards during the provision of services, among others, by the implementation of control mechanisms. It also ensures the respect for personal data and equality of patients that are not coming from their territory.

The national contact point in Member State provides essential information to patients. After the termination of care, Member State of affiliation takes over the obligation to pay costs to the insured person, provided that the care received by the patient is on the list of reimbursed benefits in his/her country. Member State of affiliation must ensure that the costs incurred by an insured person, who receives cross-border healthcare, will be refunded. The requirement is that the person must be entitled to this type of care. The refund is equal to the amount that would have been returned by a system of compulsory social insurance when treated in patient's own country. This amount does not exceed the actual costs of received healthcare. Member States were obliged to cooperate to facilitate the implementation of the Directive. Above all, they support the creation of European references network of healthcare providers, whose aim is to promote the mobility of professional evaluation in Europe and even access to highly specialized care by gathering available resources and expertise. The issue of recognition of the validity of medical prescriptions drawn up in another 
Member State has been solved too. The requirement is that the medicine must be authorized in the patient's territory. The Directive addresses the issue of rare diseases treatment. It is even more surprising in the context of no regulation about long-term care $^{13}$. New trends concerning the discussed issue have resulted in the expansion of ECJ case-law and doctrine achievements in matters relating to cross-border healthcare and health tourism.

J. Rab-Przybłowicz ${ }^{14}$ defines health tourism as a travel beyond the borders of a region or country, which main motive is to visit the clinic in order to improve health or beauty. In my opinion, the definition is incomplete, since the travel in order to visit the clinic to improve health or beauty is too broad. The thing that must be emphasized is that not all medical treatments are associated with a longer stay in a specialized medical facility, as well as not all beauty treatments need a medical interference in the body. On the other hand, it should be noted that the growing popularity of aesthetic medicine, which is an alternative to cosmetic surgery, will also have an impact on the need to redefine the concept of health tourism. In my opinion, health tourism should be define as a trip in order to obtain services through the provision of medical care, to undergo a surgery or other medical treatment, as well as to receive a medical advice or to have a rehabilitation, in which their aim is to improve the health or well-being of the patient, regardless of the source financing the trip or service. Such an interpretation of this phenomenon corresponds with the content of Regulations 883/2004 and 987/2009, which relate to sickness benefits, maternity and equivalent paternity benefits, benefits with the title of invalidity, old age benefits, survivors' pensions, benefits in case of accidents at work and occupational diseases, benefits in case of death, unemployment benefits, retirement and family benefits. This is a good moment to put up two fundamental questions, ie. Whether health tourism must always have a cross-border dimension and how the issues of health tourism based on free-market principles are regulated?

My proposal for the interpretation of the first issue is to introduce the concept of "small" and "large" health tourism which adequately relate to tourism within the country and across borders. In this text the "large" health tourism within the EU Member States will be defined. It should be

${ }^{13}$ http://europa.eu/legislation_summaries/employment_and_social_policy/social_ protection/sp0002_pl.htm [access: 27.11.2016].

14 J. Rab-Przybyłowicz, Produkt turystyki medycznej, Warsaw 2014, p. 13. 
emphasized that the phenomenon of health tourism is inextricably linked with two freedoms, ie. movement of people and services. Article 50 (currently article 57 TFE) of the Treaty establishing the European Community (EC) defines the services as services normally provided for remuneration if they are not governed by the provisions on the freedom of movements of goods, capital and people. S. Biernat correctly considers that the freedom to provide services applies only to the provision of medical services in the commercial dimension, since it is based on the fact that the service is a remitted benefit. Therefore, one must discriminate health tourism based on the character of using commercial services from cross-border healthcare, which will involve obtaining health services in a free of charge manner as a part of public healthcare ${ }^{15}$.

\section{The case-law of the European Court of Justice shaping cross-border care and health tourism}

The case law of European Court of Justice (ECJ) has a fundamental significance for the development of health tourism. It is important to note that medical care of a transboundary nature is inextricably linked with social security system. Rulings in Geraets-Smits and Peerbooms ${ }^{16}$ and Vanbraekel ${ }^{17}$ issues represent a genuine breakthrough in the jurisprudence of the Court. The subject of those two cases was the analysis of the Dutch social security system that is the system of factual benefits and medical treatment in hospitals. Both the Advocate General Antonio Saggio in case of Vanbraekel and Advocate General Ruiz-Jarabo Colomer in case of Geraets-Smits and Peerbooms stated that the treatment offered by the providers of medical services in the frame of a system of factual benefits paid directly by an insurance, but only indirectly by patients, yet it does not

${ }^{15}$ S. Biernat (eds.), S. Dudzik (eds.), D. Adamski, D. Bach-Golecka, A. Czekaj-Dancewicz, P. Dąbrowska, M. Glicz, I. Grzywacz, O. Hołub-Śniadach, K. Karasiewicz, M. Kawczyńska, I. Kawka, D. Leczykiewicz, D. Lutostańska, K. Majcher, S. Majkowska-Szulc, L. Mitrus, J. Nawrot, M. Niedźwiedź, A. Sikora, K. Strąk, M. Tomaszewska, K. Tosza, J. Wsołek, Przeptyw osób..., LEX 2009, http://lex.online.wolterskluwer.pl.

16 The judgment in Case C-157/99 Geraets-Smith and Peerbooms v. Stichting CZ Groep Zorverzekeringen, [2001] ECR, p. 5473.

17 The judgment in Case C-368/98 Abdon Vanbraekel v. Alliance Nationale des Mutualités Chrétiennes, [2001] ECR, p. 5353. 
comply with conditions of payment required by article. 49 (currently article 56 TFE) in the EC Treaty. In addition, hospital infrastructure is an integral part of the national health system, because its facilities are set up and organized by the state and financed from the public budget.

The European Court of Justice had the other opinion about the definition of medical services. TEC (currently TFE) clearly pointed out that, according to the settled case-law, medical activities are within the article. 50 of TEC (currently article 57 TFE) and there is no need to distinguish between a care provided by a hospital and a care provided outside of it. The fact that the hospital treatment is funded directly by the sickness insurance funds on the basis of agreements and pre-established rates can not result in excluding such treatment from the sphere of services within the services that are in the Treaty. According to the Court, medical service does not cease to be a provision of services because it was paid by a national health service or by a system providing benefits. There is thus no need, from the perspective of freedom to provide services, to draw a distinction by referring to whether the patient pays the costs incurred and subsequently applies for reimbursement or whether the sickness fund or the national budget pays the provider directly ${ }^{18}$. It should be noted that in the apothegm of the judgment of the European Court of Justice, referred to Watts ${ }^{19}$, alleged on the case-law, according to which the medical services provided for consideration fall within the scope of the Treaty provisions concerning the freedom to provide of services, regardless of whether care provided in the hospital or otherwise. The Court emphasized that the freedom to provide services includes the freedom for recipients of services, namely persons in need of medical treatment, going to another Member State in order to receive medical services there. In regard to the dispute about the main proceedings, the ECJ stated that Mrs Watts paid remuneration directly to the establishment located in another Member State,

18 The judgment in Case C-157/99 Geraets-Smith and Peerbooms v. Stichting CZ Groep Zorverzekeringen, [2001] ECR, p. 5473 and the judgment in Case C-385/99 V.G. MüllerFauré v. Onderlinge Waarborgmaatschappij O.Z. Zorgverzekeringen U.A. and E.E.M. van Riet v. Onderlinge Waarborgmaatschappij ZAO Zorgverzekeringen; Mark Flear, Issue 1, "Common Market Law Review" 2004, Vol 41, p. 209-233.

19 S. Biernat (eds.), S. Dudzik (eds.), D. Adamski, D. Bach-Golecka, A. Czekaj-Dancewicz, P. Dąbrowska, M. Glicz, I. Grzywacz, O. Hołub-Śniadach, K. Karasiewicz, M. Kawczyńska, I. Kawka, D. Leczykiewicz, D. Lutostańska, K. Majcher, S. Majkowska-Szulc, L. Mitrus, J. Nawrot, M. Niedźwiedź, A. Sikora, K. Strąk, M. Tomaszewska, K. Tosza, J. Wsołek, Przepływ osób, LEX 2009, http://lex.online.wolterskluwer.pl. 
in which the treatment was given. Later occurrence of a request for reimbursement of hospital care in question from a national health service must have not caused the dissent from applying the principles of freedom to provide services guaranteed by the Treaty.

In the Court's rating, medical services does not cease to provide services within the meaning of article. 49 (currently article 56 TFE), just because the patient, who paid the foreign provider for the care, later applies for the costs of this care through a national health service. The Court stated that article 49 (currently article 56 TFE) of the EC Treaty is applicable in the situation of a patient who, like Mrs Watts, received some medical services in another Member State in a hospital center for a fee, regardless of how the national system to which the person belongs and from which later seeks later to cover the costs these benefits. It is worth to refer to the judgment in the case of Luisi and Carbone, where the European Court of Justice pointed out that the freedom to provide services means the freedom of recipients of services, such as people using medical care, tourists and people staying in the studio or business trip in order to use the services on the territory of another Member State without any restrictions ${ }^{20}$. The jurisprudence of the Court is undoubtedly correct in the light of the applicable within the EU legal acts and consistent and is a valuable interpretive clue when trying to define the phenomenon of medical tourism and cross-border care.

Investigating process of shaping legal status of cross border care and health tourism is also worth mention C-158/96, Kohll case. Important judgment of European Court of Justice in this case can be base for conclusion that social protection of workers is a public interest ${ }^{21}$. Similar conclusion can be established in process of Decker (C-120/95). Those two judgment reffers to obtain health services without the consent of the insurance funds. It can be assumed that these rulings were the basis for the adoption of the position that there is no reason to arbitrarily deny patients the freedom to receive normal medical services in other EU Member States.

${ }^{20}$ Joined Cases C-286/82 and C-26/83 Graziana Luisi and Giuseppe Cabone v. Ministero del Tresoro, [1984] ECR, p. 337, Section 16.

${ }^{21}$ R. Giesen, Posting: Social Protection of Workers vs. Fundamental Freedoms?, LEX 2003, http://lex.online.wolterskluwer.pl. 


\section{Conclusions}

Summarizing, this text presented the achievements of doctrine and case-law relating to cross-border health tourism and medical care. This is the case law of the ECJ, who plays a key role in the interpretation of directives, regulations and the TEC relating to the issue in question. Determined point of view allows us to conclude that the cross-border medical care is an important practical issue. Lack of coherence in social security systems of individual Member States favors the emergence of problems covering the costs of cross-border care benefits and the possible return of money by the national social security bodies. It should be noted that the contemporary European laws fit in the case-law of the Court of Justice against the judgment in Kohll and Decker issued 28 April 1998. The judgment admitted that patients have the right to receive reimbursement of treatment in another Member State ${ }^{22}$. Directive 2011/24 / EU of the European Parliament and of the Council of 9 March 2011 show that patients' rights in cross-border healthcare do not question the main principles of the Regulation on the coordination of social security systems, particularly the principle of equality patient-residents or non-residents of the Member State and European health insurance card. The doctrine is also trying to define a legal and social phenomenon which is health tourism for many years. However, the development of freedom of movement of persons and property will affect in a way on the the escalation of this phenomenon. It will undoubtedly rise many difficulties related to national laws, especially because of trips in order to have an unauthorized treatment in one of the European countries. An issue that will require a response in the form of case law and interpretation of the doctrine is the problem of non-refundable treatments in one of the Member State, which are being made in another Member State, in which the treatment is refundable. It must be said that the number of issues requiring a response is large, because of the divergent social security systems in the various countries of the community. Finally, the main reasons for the health migration of a commercial nature are the differences in the cost of medical services. This trend can be observed especially in the aspect of a plastic surgery, where prices of medical procedures in the Member communities differ from each other,

${ }^{22}$ E. Mossialos, W. Palm, The European Court of Justice and the Free Movment of Patients in the European Union, "International Social Security Review" 2003, vol. 56, p. 11. 
sometimes in a significant way. Medical liability issues and the protection of consumers using the services of this type are considerations that are too broadand require a separate discussion. The causes of medical emigration in order to obtain non-commercial medical services can be seen in the willingness to give up to a modern medicinal therapies for a rare diseases or to obtain health benefits of higher quality than in the home country, or access to these benefits after a shorter period of waiting. The lack of regulations of long-term medical care in the EU is also surprising. It is obvious that it is the type of medical care, which is largely the reason for medical tourism in the EU. At the same time it highlights the important role of the EU in the development of medical tourism and cross-border healthcare. A freedom to receive health care throughout the European Union must be accompanied by a guarantee of quality and safety. To be aware of the choices, patients must have an access to all the information they need about the conditions of acquiring health services in the in other EU Member States and about the possibility to get reimbursement after they return home. Coherent regulations on the discussed matter can contribute in improving the quality of medical services on the territory of the European Union.

Key words: health care, medical tourism, international law, cross-border healthcare

\section{Bibliography}

Biernat S. (eds.), Dudzik S. (eds.), Adamski D., Bach-Golecka D., Czekaj-Dancewicz A., Dąbrowska P., Glicz M., Grzywacz I., Hołub-Śniadach O., Karasiewicz K., Kawczyńska M., Kawka I., Leczykiewicz D., Lutostańska D., Majcher K., Majkowska-Szulc S., Mitrus L., Nawrot J., Niedźwiedź M., Sikora A., Strąk K., Tomaszewska M., Tosza K., Wsołek J., Przepływ osób i świadczenie usług w Unii Europejskiej, LEX 2009.

De la Rosa S., The Directive on cross-border healthcare or the art of codifying complex case law, "Common Market Law Review" 2012, vol. 49.

Giesen R., Posting: Social Protection of Workers vs. Fundamental Freedoms?, LEX 2003.

Mossialos E., Palm W., The European Court of Justice and the Free Movment of Patients in the European Union, "International Social Security Review" 2003.

Rab-Przybyłowicz J., Produkt turystyki medycznej, Warsaw 2014. 


\section{TURYSTYKA MEDYCZNA \\ I TRANSGRANICZNE USEUGI MEDYCZNE W UE}

Streszczenie

W artykule przedstawiono podstawowe zagadnienia dotyczące turystyki medycznej i transgranicznej opieki medycznej w kontekście prawa Unii Europejskiej. W artykule uwzględniono orzecznictwo Europejskiego Trybunału Sprawiedliwości, a także częściowo dorobek doktryny. Autor przedstawił pozytywne i negatywne efekty zjawiska turystyki medycznej oraz transgranicznej opieki medycznej oraz okazje i zagrożenia płynące z obu tych zjawisk.

Słowa kluczowe: transgraniczna opieka medyczna, prawo międzynarodowe, turystyka medyczna

\section{МЕДИЦИНСКИЙ ТУРИЗМ И ТРАНСГРАНИЧНАЯ МЕДИЦИНСКАЯ ПОМОЩЬ В ЕВРОПЕЙСКОМ СОЮЗЕ}

\section{P e 3 ю м e}

В статье представлены основные вопросы, которые касаются медицинского туризма и трансграничной медицинской помощи в контексте права Европейского союза. В статье учтены решения Европейского суда справедливости, а также частично наработка доктрины. Автор представил позитивные и негативные эффекты явления медицинского туризма и трансграничной медицинской помощи, а также случаи и угрозы, вытекающие из обоих этих явлений.

Кдючевые слова: трансграничная медицинская помощь, международное право, медицинский туризм 